\title{
Assuring Tayyib from a food safety perspective in Halal food sector: a conceptual framework
}

\begin{abstract}
This paper puts forth how food safety and hygienic practices are a part of the Halal concept and should thus be adapted by the Halal food sector to achieve Halal and Tayyib assurance. It further puts forth the concept of Halal prerequisites, which were established through identifying food safety and hygiene requirements in Islamic Jurisprudence. To move toward more efficient Halal and Tayyib practices these should be demanded, implemented, maintained and controlled by the whole Halal food sector, instead of just relying on the existence of food safety certification. A conceptual framework was constructed depicting the Halal sector's possible passive and potential active Halal and Tayyib food safety control practices. It will enable the sector to gain insight to issues in Halal certification, food safety position within it and reach an understanding of improvement measures. The paper also suggests recognising and incorporating the Halal prerequisites and other sector specific requirements as Halal Control Points (HCPs) to the Halal HACCP system.
\end{abstract}

Volume 6 Issue 2 - 2018

\author{
Syed Fazal Ur Raheem,' Marin Neio \\ Demirci $^{2}$ \\ 'Islamic Food and Nutrition Council of America, Pakistan \\ ${ }^{2}$ Department of Food Engineering, Istanbul Sabahattin Zaim \\ University, Turkey
}

Correspondence: Syed Fazal Ur Raheem, Shariah Advisor, Islamic Food and Nutrition Council of America, (Pakistan) Office, I44-A, Peoples Colony No: 2, Faisalabad, Pakistan, Email fazalraheemI50@gmail.com

Received: February 06, 2018| Published: March 13, 2018

Keywords: tayyib, food safety, hygiene, halal, haraam, islamic jurisprudence, haccp, prps

\section{Introduction}

From raw ingredients to final products food safety assurance covers the whole supply chain. Despite that in 2010 approximately 600 million foodborne disease cases were reported globally, with an estimated 400 thousand deaths. ${ }^{1}$ Food safety assurance is thus complicated and research is constantly conducted with an aim to improve existing food safety measures, find effective approaches and identify food sector's needs. ${ }^{2-4}$ This in turn enables to analyse and understand its problems, issues and complexities and draw parallels with Halal assurance.

For Muslim consumers Halal food is an essential part of life. This is obvious from the fact that the word in Arabic denotes permissibility and that its opposite Haraam connotes impermissibility. With the Halal certification industry globally surpassing by far the value of both Kosher and Organic certified food and beverage markets, the interest towards Halal is at an all-time high. This has brought with it an on-going establishment of numerous Halal standards, the start of accreditation activities, the acknowledgement of dominant standards and industrial best practices. ${ }^{5}$ Due to the rapid growth and development of the Halal food sector, the expectation to Halal credence quality and its perception seem to be at a shift, namely, extending to include the principle of Tayyib. This is reflected by recent academic work especially on Halal integrity and Islamic economy reports suggesting Tayyib to be a new trend and a value adding factor in marketing Halal products. $^{6-10}$

The Tayyib concept has a wide scope under which various food sector issues could be discussed, ${ }^{11-13}$ however, this paper will cover the aspects of food safety. For a Muslim consumer a food is safe for consumption if it complies with requirements set by the fundamental sources of Halal and Haraam Jurisprudence, namely the Quran and the Sunnah. Sunnah is the sayings, practices and approvals of the Prophet (P.B.U.H.) that have legal content but when it comes to the form of mere text then it is called Hadith. ${ }^{12}$ In the context of this paper food safety will be referred to as a concept that focuses on food that is injurious to health. ${ }^{14,15}$

The actual aim of Halal certification is to promote trade and maximise consumer choice. However, the varying scopes of Halal standards and ways of recognising Halal certification bodies have led to an overall global diversification of the Halal sector, possibly leading to the reduction of trade, limiting consumer food choice and the emergence of different interpretations. ${ }^{7,16}$ Food safety (Tayyib) in the Halal sector is an emerging area with differences in understanding and practicing the concept. While some say, it is a part of the sector others do not. ${ }^{9}$ Additionally, even if some Halal standards demand a certain level of food safety, it is even less clear how these are translated to the Halal certification bodies' control measures during the certification process. ${ }^{17,18}$ This situation is worrisome especially because Muslim and even some non-Muslim consumers perceive the "Halal" mark to encompass food safety activities among others. ${ }^{9}$

The paper aims to explore whether and to what extent food safety is a part of the Halal and Tayyib concept and how that is currently backed up by the Halal food sector. The findings will enable to move toward more efficient Halal and Tayyib policies and improve the food sector's practices.

\section{Fundamentals of halal-food sources}

Making sure that food, its ingredients, additives and processing aids are of the proper source and treatment is the starting point for the Halal food sector. With the onset of processed foods, it has become 
difficult, even nearly impossible for the consumers by themselves to have information and clarity of the origins of substances added to food, especially when it is not compulsory to declare all of them. ${ }^{19}$ Thus, a need of competency, vigilance and a great responsibility lies on Halal certifiers. Interestingly enough, even though the sector has adopted itself the name "Halal", it is inherently encompassed by a wider concept called Tayyib. Namely, to declare any food source as prohibited, the crux is its non-Tayyibness. ${ }^{11-13}$ This is also the basis on which some of the requirements brought out below are derived from. In Halal related literature, the discussion often revolves around the main prohibitions, namely the consumption of pork, blood, carrion, and animals not slaughtered according to Islamic requirements, intoxicants and products thereof. ${ }^{12}$ In addition to what is explicitly prohibited, there are also other nuances, like a mammal or bird amongst the land animals and their products, like eggs and milk, to be deemed as suitable for Muslim consumption they should be solely herbivores (e.g. sheep, goat, camel, cattle, rooster, pigeon, dove, quail and sparrow). This is explicitly promulgated by the following:

i. Ibn Abbas reported that Allah's Messenger forbade (the eating) of all the fanged beasts of prey, and of all the birds having talons. ${ }^{20}$

ii. Among cattle (He has created) those fit for loading and those fit for laying on the floor. Eat of what Allah has provided you, and do not follow the footsteps of Satan. Surely, he is an open enemy to you. (Allah has created) eight pairs: two of sheep and two of goats. And (He has created) two of camels and two of oxen. (Quran, 6:142, 143, 144).

iii. You who have believed, fulfil your contracts. The brute of cattle (cattle, camels, sheep and goats) has been made lawful to you. (Quran, 5:1).

In Islamic Jurisprudence carnivores and omnivores are not considered Tayyib for consumption. This is because carnivores are predators; they eat from the flesh of other animals and omnivores have the aspect of carnivores as they are opportunist and at times also eat from the flesh of animals. In addition to obtaining food from a permissible source, mammals and birds need to be properly slaughtered. In this process the trachea, oesophagus, carotid arteries and jugular veins are severed without injuring the spinal cord. ${ }^{21}$ This process has been exhibited in Table 1 .

Table I Texts from the Quran regarding the Islamic food safety principle of Tayyib

\begin{tabular}{ll}
$\begin{array}{l}\text { Chapter and Verse } \\
\text { from the Quran }\end{array}$ & Relevant Texts \\
\hline 2:168 & $\begin{array}{l}\text { O mankind, eat from whatever is on earth [i.e.,] lawful and good and do not follow the footsteps of Satan. Indeed, he is to you a } \\
\text { clear enemy. } \\
\text { 7:157 }\end{array}$ \\
And makes lawful for them the good things and prohibits for them the evil. \\
And do not throw (yourselves) by your (own) hands into destruction and do fair deeds; surely Allah loves the fair-doers.
\end{tabular}

In the herbivore category, there are some amount of mammals that are not permissible, like donkey and elephant. Donkey has explicitly been prohibited by the prophet (P.B.U.H.) and it is fundamentally used for loading while elephant cannot be slaughtered according to the Islamic principles due to its physics. ${ }^{12}$ Variety of interpretations prevails regarding aquatic animals but only fish with scales is unanimously allowed. ${ }^{12}$ Permissibility of arthropods is also a diverse topic, however, all the venomous species are unanimously deemed as non-Halal and locust as Halal. Furthermore, all the amphibians are deemed as non-Halal and among the reptiles only Dhub lizard (spinytailed lizard) is considered as Halal. Toxic and intoxicating substances are also impermissible, which is also the case regarding food of plant origin and drinks. ${ }^{12,13}$

It becomes apparent from the above mentioned requirements that Islam only permits what it considers safe and suitable for consumption and the same has been demonstrated by laying down the principle of Tayyib. Furthermore, the above mentioned requirements are only covered by Halal certification and are thus rightly the main emphasis in Halal standards, certification and policies. This is also coupled by the fact that food safety already has its own constantly evolving practices in place, which bolster the Halal sector.

\section{Understanding the principle of Tayyib}

Having clarified the fundamental requirements that set the foundation of Halal, this paper will continue by focusing on how Tayyib lays down the principle of food safety. Firstly, it is important to understand, that the Quran is the book of principles and fundamental guidelines leading people in all trades of life and Muslims are expected to use the best possible measures to comply with them, which becomes apparent from the verse (10:37) in the Quran. The most relevant verses to explain the Tayyib concept are brought out in
Table 1. With the verse (2:168) the Quran lays down the principle of Tayyib regarding eating. In this verse, "lawful" is the translation of the Arabic term "Halal" while "good" is the translation of Arabic term "Tayyib". Thus, the verse states that in order to consume a thing it must not only be Halal but it shall also be Tayyib. In the verse (7:157), Tayyib or "good things" are contrasted against the Arabic word "AlKhaba'ith", which is translated as "the evil", meaning things that are impure, disgusting and harmful. ${ }^{21}$ Therefore, this verse states a ruling that impure, abominable and harmful things or in other words what is opposite of Tayyib are unlawful to consume. ${ }^{12}$ This is also supported by the classical definitions of Tayyib, which are as follow:

i. A thing which is not abominable, which is attractive and which a sound mind person considers good for health. ${ }^{23}$

ii. Tasty, delicious, wholesome, free from hazards to health. ${ }^{24}$

iii. Free from hazards to health, delicious and nourishing. ${ }^{25}$

iv. A thing that is medically suitable for consumption. ${ }^{22}$

The fact that food safety is an intrinsic part of Halal is further strengthened by the verse $(2: 195)$ in the Quran, stating that people should keep away from every kind of destruction, including harm from food. In food sector the verse $(2: 195)$ can be translated as to prevention from and avoiding the hazard, which is defined as an agent that is reasonably likely to cause illness or injury in the absence of its control. It is categorised as biological, chemical and physical hazards. From the biological, physical and chemical type of hazards biological ones especially pathogenic bacteria are most common and have caused the most harm to consumers. ${ }^{26}$ Therefore, it is obvious that during any kind of food handling, hazards should be well understood and best possible measures taken to prevent them. Furthermore, this verse ensures food handlers a safe and sound working atmosphere. 
Since Tayyib sets the general principle for assuring food safety in the Halal sector, all other texts regarding Islamic Jurisprudence reflecting measures of guidance towards a better food safety performance, will be expanded upon as a part of the Tayyib scope.

\section{Food safety measures in Islamic jurisprudence}

It is apparent that Halal food production should comply with both Halal fundamental and food safety requirements. Therefore, it is important to consider how Halal standards and policy makers and especially certifiers would be able to successfully enforce the implementation and maintenance of these two great areas and accordingly educate the food handlers. Especially since research to comprehend Halal compliance itself is lacking. There have only been a few studies on the issues arising during Halal production ${ }^{10,27,28}$ and on barriers and success factors to Halal assurance management. ${ }^{29-33}$ Thus far this paper has examined the fundamental food sources of Halal, followed by a more focused discussion on how food safety is associated with the concept. Since Islamic Jurisprudence also offers some more detailed guidance relevant to food safety, these will be discussed in this paper, as they constitute an inherent part of the Halal and Tayyib concept. This will be of value in guiding the discussion around the conceptual framework and making recommendations for possible assurance approaches. For the sake of clarity relevant measures were grouped according to their content as follows:

$$
\begin{aligned}
& \text { i. operational environmental hygiene } \\
& \text { ii. personal hygiene }
\end{aligned}
$$

iii. hygiene and faecal contamination

iv. other cross-contamination issues

These all lead a food handling company towards a better food safety performance and with that enables them to prevent harm coming to the consumer.

Before elaborating on the specifics, it is important to understand, that purity, cleanliness and hygiene are centric in Islam which becomes apparent from the Hadith, in Table 2. ${ }^{20,34,35}$ Purity, cleanliness and hygiene have been emphasized from its onset, since among the earliest revelations to Prophet Muhammad (P.B.U.H.) was the verse "And so your clothes purify."22 The phrase "pure", includes every kind of purity like good character, clean clothing, personal hygiene and cleanliness of the surroundings among others. Therefore, in general food-handling setting, its surroundings and food-handlers should maintain a constant state of the best possible purity. Cleanliness and purity from a food safety perspective lead to a higher level of hygiene

\begin{tabular}{|c|c|c|}
\hline $\begin{array}{l}\text { Collector and } \\
\text { number of Hadith }\end{array}$ & Relevant Texts & Reference \\
\hline Sahih Muslim, ${ }^{20} 1015$ & Allah is pure and He accepts only what is purely good. & 20 \\
\hline Sahih Muslim, ${ }^{20} 223$ & Purity is half of the faith. & 20 \\
\hline Nasa'i, ${ }^{35} 77$ & Come to a means of purification and a blessing from Allah. & 35 \\
\hline Ibn Majah, ${ }^{37} 328$ & $\begin{array}{l}\text { Discharging oneself in watering places, in places of shade and in the middle of the street provoke the curse } \\
\text { of Allah. }\end{array}$ & 37 \\
\hline Sahih Muslim, ${ }^{20} 550$ & $\begin{array}{l}\text { Abu Huraira reported that the Messenger of Allah (P.B.U.H) saw some sputum in the direction of the Qibla } \\
\text { of the mosque. He turned towards people and said: How Is it that someone amongst you stands before his } \\
\text { Lord and then spits out in front of Him? Does any one of you like that he should be made to stand in front } \\
\text { of someone and then spit at his face? }\end{array}$ & 20 \\
\hline Sahih Muslim, ${ }^{20} 553$ & $\begin{array}{l}\text { Abu Dharr reported:The Prophet of Allah (P.B.U.H) said:The deeds of my people, good and bad, were } \\
\text { presented before me, and I found the removal of something objectionable from the road among their good } \\
\text { deeds, and the sputum mucus left unburied in the mosque among their evil deeds. }\end{array}$ & 20 \\
\hline Ibn Majah, ${ }^{37} 368 I$ & Remove harmful things from the path. & 37 \\
\hline Sahih Muslim, ${ }^{20} 35$ & $\begin{array}{l}\text { Faith has over seventy branches or over sixty branches, the most excellent of which is the declaration that } \\
\text { there is no god but Allah, and the humblest of which is the, removal of what is injurious from the path. }\end{array}$ & 20 \\
\hline Abu Dawood, ${ }^{39} 382$ & The earth becomes Pure when dry. & 39 \\
\hline Abu Dawood, ${ }^{39} 386$ & When any of you treads with his shoes upon something unclean, they will be purified with the earth. & 39 \\
\hline
\end{tabular}
and through that potentially lower occurrence of food borne disease. ${ }^{36}$

\section{Operational environment hygiene}

Surroundings have a great impact on people's health and wellbeing. Clean environment is also a crucial aspect in achieving a high level of food safety. . Contamination of the food-handling environment has to be prevented, which in turn enables to prevent the contamination of products. ${ }^{14,15} \mathrm{~A}$ fundamental aspect of Tayyib is cleanliness and hygiene of the surroundings. It would be identified from the quoted Hadiths that Islam is very much sensitive regarding the environment outside the food establishment in routine course of life, hereafter it can be imagined that how more it will be thoughtful with respect to operational environment, therefore these texts will be translated from the routine course of life to the food establishment's operation environment hygiene. From a food safety perspective, the Hadiths on purity in Table 2 emphasize the importance of achieving and maintaining a hygienic food-handling environment. The Hadith and highlight respect towards cleanliness of public places. ${ }^{37,38}$ The Hadiths, and part of the third Hadith are about removing anything that is disturbing to human health, environment and common taste, like garbage, waste, sewage among others, from the surroundings..$^{20,37,38}$ From the Hadiths and it is clear, that the dryness of the soil is an indicator of its cleanliness and that clean earth could be used to clean ones self from impurities. ${ }^{39}$ Therefore, food-handlers should have proper respect for their work place, keep it clean and tidy. The food-handling area and equipment should be kept in a hygienic state, free from excess things and take precaution against pest, waste accumulation, leakages and any kind of mess and negligent storage. Food-handling establishments' floors should allow adequate drainage and cleaning. Overall, the design and layout should create a hygienic environment to conduct proper food handling operations. 


\section{Personal hygiene}

According to verses $(9: 108,4: 43,5: 6)$ in the Quran, bodily cleanliness is a vital daily practice in Islam. These verses in addition to Hadiths in Table 3 highlight bodily hygiene and the importance of using water when cleaning ones' self, ${ }^{39,40}$ keeping clean after using the toilet, washing hands up until the elbows and feet up until the ankles, washing the face, neck and ears and rubbing the head with water. The Hadith additionally highlight personal grooming, ${ }^{35,37-39}$ especially taking care of any kind of hair on the body and nose and mouth hygiene. Siwak or tooth stick has a significant place in Islamic hygiene practices. It is an inexpensive, simple tool to take care of oral hygiene. ${ }^{41}$ Other methods, like tooth brush could be used as well. These injunctions have primarily been promulgated to the mankind in his individual and personal life but all are more needed in his social and collective life. These are all relevant aspects, which would positively impact a food-handling companies' overall level of food safety. ${ }^{42}$ From fingernails to the gastrointestinal (GI) tract, people carry with them a reservoir of hundreds of different microorganisms

Table 3 Texts of Hadith regarding food handler personal hygiene in Islamic Jurisprudence with some being naturally present and others obtained through daily activities, with some of them being supportive to our bodily functions and others destructive. Concerning the outer surface of the body face, neck, hands and hair harbour a higher amount of microorganisms compared to other parts. ${ }^{36}$ Daily bathing of a food handler has been suggested as a measure to achieve a sufficient level on personal hygiene, since it directly influences the type and the amount of microflora on the skin. ${ }^{43,44}$ It is clear that personal hygiene concerns in the food industry are addressed by the Tayyib concept. On the other hand, current industrial best practices are important in achieving its proper assurance in the Halal food industry. Keeping the mouth and nose clean and healthy and regularly brushing teeth considerably reduces the amount of microorganisms present and with that the degree of potential food contamination. Eyes and ears of the food handler are not considered as a serious source of contamination, if not infected. On the contrary, mouth and nose contain significant amounts of microorganisms, which have also been found from food handlers' hands during food preparation. ${ }^{36}$

\begin{tabular}{|c|c|c|}
\hline $\begin{array}{l}\text { Collector and } \\
\text { number of Hadith }\end{array}$ & Relevant Texts & Reference \\
\hline Tirmidhi, ${ }^{40} 33$ & $\begin{array}{l}\text { The Prophet wiped his head two times: He began with the rear of his head, then with the front of his head and } \\
\text { with both of his ears, outside and Inside of them. }\end{array}$ & 40 \\
\hline Tirmidhi, ${ }^{40} 36$ & The Prophet wiped his head and his ears: the outside and the inside of them. & 40 \\
\hline Abu Dawood, ${ }^{39} 132$ & $\begin{array}{l}\text { Narrated Talhah ibn Musarrif that I saw the Messenger of Allah wiping his head once up to his nape. Musaddad } \\
\text { reported: He wiped his head from front to back until he moved his hands from beneath the ears. }\end{array}$ & 39 \\
\hline Ibn Majah, ${ }^{37} 294$ & $\begin{array}{l}\text { Part of the nature is rinsing out the mouth, rinsing out the nostrils, using the tooth stick, trimming the mustache, } \\
\text { clipping the nails, plucking the armpit hairs, shaving the pubic hairs, washing the joints, washing the private parts } \\
\text { and circumcision. }\end{array}$ & 37 \\
\hline Nasa'i, ${ }^{35} 02$ & When the Messenger of Allah got up from sleep, he would brush his mouth with the Siwak. & 35 \\
\hline Sahih Muslim, ${ }^{20} 238$ & When any one of you wakes from the sleep, he must clean his nose three times. & 20 \\
\hline $\begin{array}{l}\text { Abu Dawood, } \\
4163\end{array}$ & He who has hair should honour it. & 39 \\
\hline
\end{tabular}

\section{Hand hygiene and faecal contamination}

From the texts in Table 4, it becomes obvious that despite the focus on food-handler hygiene, the Tayyib concept zooms in on hand washing practices and protecting ones' self from faecal matter. Poor food handler hygiene, especially lacking hand washing is deemed one of the main causes of food borne disease. ${ }^{36,45}$ the skin through everyday activities. They reside on the superficial layers of the skin and are also removable through routine hand hygiene practices. ${ }^{14,15,36}$ Washing three times indicates a longer duration and rubbing of hands during washing and washing in between the fingers indicate sensitive regions of the hands that are easily contaminated, hence these must be cleaned ${ }^{35,40}$ Washing hands before and after being in contact with food indicates proper timing of hand washing. These constitute valuable advice to achieve clean hands and avoid cross-contamination in a food handling setting. ${ }^{39}$

A wide range of pathogens has been identified in faecal matter, which makes faecal contamination of food- handlers a great concern. ${ }^{36,43}$ Food-handlers' clothes not to mention hands could come in contact with faecal matter when using the toilet. This could in return lead to the contamination of work surfaces and equipment when a worker moves around the factory. Hands may come in contact with these areas and finally transfer pathogens to food. ${ }^{36}$ It is of the utmost importance that food-handlers would avoid contact with faecal matter. This is also promulgated by Hadiths in Table 4..$^{35,37,38,40}$ Before leaving the toilet, food-handlers should make sure their hands and clothes are clean.

Table 4 Texts of Hadith regarding hand hygiene and faecal contamination in Islamic Jurisprudence

\begin{tabular}{|c|c|c|}
\hline $\begin{array}{l}\text { Collector and } \\
\text { number of Hadith }\end{array}$ & Relevant Texts & Reference \\
\hline Nasa'i, ${ }^{35} 0 \mathrm{I}$ & $\begin{array}{l}\text { When any one of you wakes from sleep, let him not touch anything with his hands (for consumption } \\
\text { or for any other use) until he has washed it three times, for none of you knows where his hand spent } \\
\text { the night. }\end{array}$ & 35 \\
\hline Tirmidhi, ${ }^{40} 38$ & While washing hands, go between the fingers. & 40 \\
\hline Abu Dawood, ${ }^{39} 3761$ & The blessing of food consists in washing hands before and after it. & 39 \\
\hline Ibn Majah, ${ }^{37} 348$ & Most of the punishment of the grave is because of urine. & 37 \\
\hline Nasa'i, ${ }^{35} 47$ & Do not wipe yourself with right hand. & 35 \\
\hline Sahih Bukhari, ${ }^{38} 5376$ & Mention the Name of Allah and eat with your right hand, and eat of the dish what is nearer to you. & 38 \\
\hline
\end{tabular}




\section{Other cross-contamination issues}

Table 5 indicates a focus on some specific cross-contamination issues relevant in the food safety context. Namely, the importance of proper work clothing, correct storage and packaging. Firstly, according to the verse (74:4) in the Quran, which has already been highlighted in the beginning of this section, and the Hadith, ${ }^{46}$ food handlers should wear suitable protective work clothing and be provided with adequate facilities to change in a clean manner without contamination. Wearing white clothes is also widely practiced in food establishments, mainly because it allows evaluating their cleanliness and deciding upon a time to change them. Regarding proper storage and packaging, contamination of food could also take place through

Table 5 Texts of Quran and Hadith regarding some cross-contamination issues in touching or wiping the mouth or nose, coughing, sneezing or spitting. During coughing and sneezing droplets from mouth and nose could travel a significant distance and contaminate the surrounding workers, food and equipment. ${ }^{36}$ Therefore, if a food handler should take care not to breath, let alone sneeze or caught, into their own vessels, they should take extra care not to do that into other containers. This is highlighted in the Hadith. ${ }^{35}$ The Hadith indicates that containers and finished products in a food handling setting should be kept covered and raw material and final product packages closed. ${ }^{20}$ In addition, packages, both raw material and final product, should have a proper design to protect products from contamination from air, pests and a wide range of other hazards. These all constitute valuable advice to prevent cross-contamination in a food handling setting.

\begin{tabular}{lll}
\hline Collector and number of Hadith & Relevant Texts & Reference \\
\hline Riaz us saliheen, ${ }^{46} 02$ & $\begin{array}{l}\text { Wear white clothes because they are the purest and they are closest to } \\
\text { modesty. }\end{array}$ & 46 \\
Nasa' ${ }^{3,}{ }^{35} 47$ & When any one of you drinks, let him not breath in to the vessels. & 35 \\
Sahih Muslim, ${ }^{20} 2012$ & Cover vessels, water skins, close the doors and extinguish the lamps. & 20 \\
\hline
\end{tabular}

\section{Assuring Tayyib in the halal food sector}

Keeping the above jurisprudential discourse in mind, for the first time this paper puts forth a detailed account of how food safety and hygiene form an intrinsic part of Halal assurance. Therefore,

$$
\begin{aligned}
& \text { i. ensuring a hygienic operational environment } \\
& \text { ii. ensuring the food handler's personal safety } \\
& \text { iii. ensuring that food handlers have and maintain proper personal } \\
& \text { hygiene }
\end{aligned}
$$

iv. ensuring proper and clean lavatory and hand washing facilities

v. ensuring proper use of toilet and hand washing techniques by food handlers

vi. ensuring proper and clean work clothing

vii. keeping any kind of vessels containing edible substances closed during production

viii. ensuring product packaging integrity

Take the role of Halal food manufacturing prerequisites or for short Halal prerequisites. These requirements apply for the whole food sector and do not change with regards to what is being produced. Thus, these should be rooted in Halal standards, Halal certifiers' control and food production companies' and assurance practices. Therefore, before making any further conclusions and recommendations regarding Tayyib assurance in the Halal food sector the next section puts forth food safety and hygiene requirements in Halal standards and certification, in order to see whether they reflect the intrinsic values of Halal credence quality.

\section{Halal standards and certification}

Food safety and Halal standards are a part of third party certification schemes. Third party certification is often used to remedy transparency shortcomings and with that loss of trust in the supply chain. ${ }^{47,48}$ At present an official benchmark Halal standard does not exist, which leads us to explore food safety requirements in different Halal standards. ${ }^{7}$ At present, globally leading Halal standards are OIC/ SMIIC 1:2011, ${ }^{49}$ which is aimed to become internationally accepted and the Malaysian governmental standard MS1500:2009, which is considered as industry's best practice and serves as a basis for various other Halal standards. ${ }^{49}$ In recent years, new national Halal standards have been released by Pakistan in 2016 and United Arab Emirates (UAE.S $2055-1: 2015$ ) in 2015. ${ }^{51}$

The OIC/SMIIC ${ }^{48}$ and PS $^{50}$ Halal standards include CAC hygiene principles and $\mathrm{ISO}^{52,53}$ standards, define PRPs and the cold chain and finally specifically elaborate on hygiene practices. This is because the Pakistan standard is somewhat based on the OIC/SMIIC ${ }^{49}$ standard, however it additionally includes a conformance clause with applicable regulatory food safety requirements..$^{50,52,53}$ The Malaysian standard also includes regulations and contains some detailed requirements for a hygienic food handling environment and practices. ${ }^{54}$ The UAE.S 2055 -1:2015, however, refers to the Gulf Standardization Organization's GSO 1694: General principles of food hygiene standard, without giving any specific guidance on hygiene or other food safety measures. ${ }^{51}$

As for Halal standards on logistics and the supply chain, the IHIAS 0100:2010 standard highlights PRPs, maintaining the cold chain in addition to referring to the MS1500:2009 and ISO 22000 standards. $^{55}$ Additionally, the Malaysian Halal-Toyyiban assurance pipeline standards for transportation, warehousing and retailing demand compliance with the $\mathrm{MS}^{54}$ standard and repeats its requirements on premises and personnel hygiene, health status and personnel cleanliness, in addition to defining and demanding compliance with the Tayyib concept. The Malaysian Halal-Toyyiban assurance pipeline standards define the Tayyib concept as follows:

"Complements and perfects the essence (spirit) of the basic standard or minimum threshold (halal), i.e. on hygiene, safety, sanitation, cleanliness, nutrition, risk exposure, environmental, social and other related aspects in accordance to situational or application needs; wholesomeness.". ${ }^{66-58}$

It is obvious that food safety is in one way or the other a part of the major Halal standards. However, this is with considerable variation and insufficient detail, considering the inherent detail of the Halal prerequisites. In Halal standards, a trend seems to be to include compliance with international acknowledged general hygiene guidelines and food safety standards to assure Tayyib. The OIC/ $\mathrm{SMIIC}^{48}$ has included $\mathrm{ISO}^{52,53}$ standard giving it a great significance 
in the Halal arena.

Even if the standards were to be sufficient, it is completely a separate matter how Halal certification takes place. The time of the audit, number of auditors and the emphasis of the audit have a great impact on not only how Halal fundamental requirements are assessed, but also on whether food safety is included in the assessment or not. ${ }^{17}$ highlighted that multiple Halal standards cause ambiguity in Halal certification. ${ }^{17}$ This is coupled by the fact that there are a vast number of certifiers who are of different size and competency and that, new Halal standards might raise adoption and implementation issues.

At present, it is unclear to what extent food safety requirements are considered during the Halal certification process. No set of documented procedures exist on how much time and effort should go into evaluating compliance with Halal requirements during Halal certification, let alone how big a part of it should food safety assessment be. Although, food safety management systems, food safety regulations and food codes cover the food supply chain, despite that foodborne disease outbreaks are not only still occurring in large numbers, but are also associated with companies, which have previously passed food safety controls with successful results. ${ }^{59,60}$ The on-going struggle with foodborne disease, varying uptake of food safety standards, drawbacks in food safety assessment and from country to country changing food safety approaches, scopes and enforcement possibilities should be a clear sign to the Halal sector that food safety issues are not to be ignored. ${ }^{61-64}$

Generally, food-handling companies are forced to have at least some kind of food safety measures in place by the government or a customer, inevitably forming a baseline of food safety for the Halal sector. Due to these existing food safety measures, the Halal sector anyway assures both Halal and Tayyib. There is just the question of extent and efficiency. However, it is important to differentiate that if the Halal certifiers do not assess food safety issues during audits, the Halal certificate itself does not reflect Tayyib control practices.

If Halal certifiers were to rely on checking for the existence of food safety certificates, they should take into consideration that this kind of third party certification only gives a snapshot of the food safety situation in a company, not demonstrating its daily practices. Additionally, even within the same food safety certification schemes there are significant inconsistencies in auditing quality. ${ }^{64,65}$ However, it is reassuring that companies with food safety certification have better food safety measures in place compared to non-certified companies. ${ }^{51,66}$ Furthermore, research has shown that the size of food-handling companies also affects their food safety performance. Namely, small and medium sized enterprises (SME) have been shown to have difficulty in implementing and maintaining food safety measures. ${ }^{67-70}$ Therefore, it is important for Halal certifiers to demand a reputable accredited auditing organization to back up a food-handling company's food safety certificate. ${ }^{63}$ To completely take advantage of food safety certification, Halal certifiers should review the results of the food safety audit; understand the risks addressed by the standards and make risk-reduction decisions based on the results. ${ }^{59}$ Regarding the SME the Halal certifiers should not only be more cautious about food safety, but also for Halal criteria implementation.

\section{Halal prerequisites and HACCP}

This paper takes a step even further and puts forth the concept that Halal prerequisites should be implemented as Halal Control Points (HCP) in addition to Halal Critical Control Points (HCCP).
The HCCP reflects the fundamental Halal requirements discussed above. Thus far, previous studies have suggested using the HACCP system for only HCCPs. A breach of HCCPs has been characterised as leading to critical failure, in which case the product would lose its Halal status. ${ }^{71}$ On the other hand, breach of HCPs would not result in complete rejection of the product, but it would give valuable insight on how well Halal assurance measures are in place and whether there is a need for improvement.

To the best of our knowledge for the first time, this paper offers a more detailed approach to the concept of HCPs and puts forth HCP for personnel hygiene and production environment sanitation, which apply for the whole Halal food sector. Taking into consideration the previous discussion on food safety measures in Islamic Jurisprudence, HCPs in a food handling setting would encompass the following:

i. Proper sanitation schedules, cleaning procedures and instructions.

ii. Proper lavatory and hand washing facilities.

iii. Detailed personal hygiene and hand washing instructions.

iv. Maintenance of proper operational environment hygiene.

v. Food handlers should have safe environment for working.

vi. Employees should wear proper clean work clothing.

vii. Packages/ containers/ vessels of ingredients, additives, processing aids and products at any stage of production should be kept covered/closed and proper clean packaging used.

Since avoiding faecal contamination in Halal production is an important concern, these HCPs could be added as an extra precautionary measure.

i. Microbiological analysis sampling plan to monitor faecal contamination.

ii. Proper lavatory and hand washing facilities should not be close to the production lines/equipment/products.

Thus, HCPs should be included to the Halal HACCP system principles. This would take the following form:

i. Conduct hazard analysis for non-Halal substances and non-Halal practices;

ii. Determine HCPs and HCCPs;

iii. Establish HCCPs and HCPs critical limits;

iv. Establish HCPs and HCCP monitoring procedures;

v. Establish corrective actions to be taken when monitoring indicates that a particular HCPs, HCCP is not under control;

vi. Establish verification procedures;

vii. Establish documentation and record keeping including the disposal of products after HCCP failure.

The HCPs mentioned so far concern employee hygiene, safety and production environment sanitation; however, different food sectors have additional specific HCPs (Table 6), (Figure 1). These, sector specific HCPs should be implemented in addition the Halal prerequisites discussed earlier.

The HACCP system is seen as a solution to achieve a better food safety performance, which thus makes it appealing to the Halal sector as well. However, there is some drawback. Firstly, effective 
application of HACCP requires thorough theoretical and practical knowledge from both Halal certifiers and food-handling companies. Unfortunately, this is not what the food sector currently reflects. ${ }^{64,72} \mathrm{In}$ turn, Halal assurance might not get the desired effect or even worse lead to a false sense of security. Secondly, adjusting the HACCP system to include Halal would require an extra amount of different controls, which could be difficult to manage and time-consuming to control, leading to a decrease in both Halal and food safety performance..$^{73}$ In this case, the companies could consider hiring extra personnel and might prefer to establish separate HACCP systems for food safety and HACCP. This is definitely an area, which needs further research. ${ }^{74,75}$ Table 6 HCCPs and HCPs in Halal meat and poultry slaughte

Table 6 HCCPs and HCPs in Halal meat and poultry slaughte

$\begin{array}{ll}\text { No. HCCP } & \text { The animal/bird to be slaughtered shall } \\ \text { be halal } & \text { Only animals/birds fed on Halal feed are } \\ \text { permitted for slaughtering } \\ 2 \quad \begin{array}{l}\text { The animal/bird to be slaughtered shall } \\ \text { be alive at the time of slaughter } \\ \text { The slaughterer shall be a profound } \\ \text { Muslim } \\ \text { The slaughterer shall invoke the name } \\ \text { of Allah while severing the trachea, } \\ \text { esophagus and both the carotid artery } \\ \text { and jugular vein. }\end{array} \\ 5 \quad\end{array}$

6

7

\section{HCP}

Merciful treatment of animals, hence, they must be treated as such that they are not stressed or excited prior to slaughter. Holding areas for cattle should be provided with drinking water, animals should be nourished and well rested.

Hygiene and sanitation of personnel and the production environment, including sufficient sanitation schedules, cleaning procedures and instructions, lavatory and hand washing facilities, detailed personal hygiene and hand washing instructions and clean work clothing.

The slaughter knife must be sharp. The size of the knife (blade length) should be proportioned to the size of the neck. The knife must not be sharpened in front of the animal.

It is preferred that the animal would be faced towards Qibla during slaughter.

When the bleeding has ceased, the heart stops, and the animal is dead, one may start further acts of processing the carcass. It is abominable to sever parts such as ears, horn, and legs before the animal is completely lifeless.

Packing is done to clean packages and boxes, and proper labels are affixed to facilitate traceability.

Packages/ containers/ vessels of ingredients, additives, processing aids and products at any stage of production should be kept covered/closed and proper clean packaging used.

Ingredients, additives, processing aids and products at any stage of production should be properly stored. Halal and non-Halal ingredients should have their designated areas. Halal and non-Halal food should not be placed or stored side-by-side and non-Halal products on top of Halal products.

\begin{tabular}{c|c} 
Animal & HCCP 1 \\
\hline Receiving and Holding & HCCP 2; HCP 1 \\
\hline Slaughter & HCCP $3,4,5 ; \mathrm{HCP} 2,3,4$ \\
\hline Skinning; Evisceration and & HCP 2,5 \\
\hline Deboning & HCP 2, 6, 7,8 \\
\hline Packing &
\end{tabular}

Figure I Flowchart with HCCPs and HCPs for meat and poultry production.

\section{Construction of the conceptual framework}

As discoursed earlier that the number of people every year suffering from food borne diseases is without a doubt worrisome, especially with acknowledged food safety schemes and measures being widely used by the food sector. From the Halal perspective, this is important because in addition to its foundational requirements Halal is encompassed by the Tayyib concept, which stipulates food safety. Generally, food-handling companies are forced to have at least some kind of food safety measures in place by the government or a customer, inevitably forming a baseline of food safety for the Halal sector. Therefore, for the Halal standards makers and certifiers it is suggested to take advantage of already existing food safety practices and research, instead on pursuing the same goal separately and by doing that not to depend exclusively on food safety certificates but it is advised to follow the complete process. This would allow transforming the Tayyib concept from theory to reality, which is also suggested by the conceptual framework (Figure 2).

The fundamental requirements, namely the HCCPs (Figure 2.1.1) form the foundation and the main emphasis of Halal standards and certification. Food safety (Tayyib) fits into that scope as a passive or active approach. The foundation requirements in the conceptual framework are depicted as HCCPs, because whether or not there is a documented HACCP system for Halal in place, these remain critical points for Halal assurance in any case. However, to uphold these requirements and to improve Halal assurance the standards should demand and the certifiers should have competence in Islamic Jurisprudence (1.2), like appointing an Islamic affairs advisor, and food sector's practices (1.3), like appointing a food scientist, and have in place sufficient control measures (1.4), like audit lengths, number of auditors, their competency and a notification policy. Additionally, taking into account whether these companies have previously implemented any other schemes (1.5) and the size of food-handling companies (1.6) would give some insight on how well companies might adopt with the Halal concept and enable Halal certifiers to 
modify their approach accordingly. This would ultimately enable to achieve a better Halal and Tayyib performance.

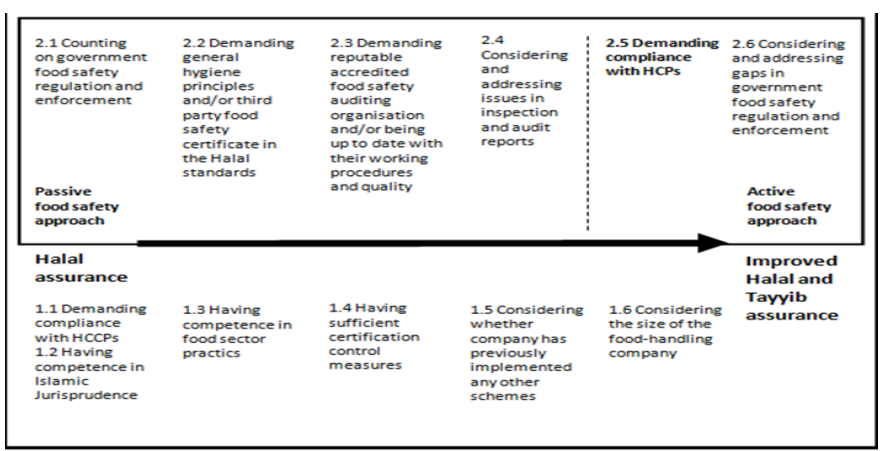

Figure 2 A conceptual framework is presented for Halal foundation and assuring Tayyib from a food safety perspective in the Halal food sector.

Within the Halal assurance scope, food safety might have a passive or an active position in the standards and the certification process. The passive approach depicts the current situation in which food safety issues are minimally considered. In this case, Halal assurance relies on the existence of food safety certificates, hygiene principles and regulations (Figure 2. Points 2.1-2.2). Since food safety is an intrinsic part of the Halal concept, it is discouraged and mentioned in this portion to compare it with the active approach, which is the main theme of conceptual framework.

In Halal standards, a trend seems to be to include compliance with international acknowledged general hygiene and food safety standards to assure Tayyib. For example, the OIC/SMIIC ${ }^{48}$ has included $\mathrm{ISO}^{52}$ standard giving it a great significance in the international Halal arena. The fact that companies, which have implemented food safety schemes, have been able to achieve a better food safety performance is reassuring. Despite that, Halal certifiers should be cautious regarding possible control measure inconsistencies within the same scheme and take into consideration that this kind of third party certification only gives a snapshot of the food safety situation in a company, not demonstrating its daily practices. Therefore, as a minimum the Halal standards and certifiers should demand a reputable accredited auditing organization to back up a food-handling company's food safety certificate (Figure 2. Point 2.3). In addition to considering and addressing issues in food safety inspection and audit reports (2.4). Additionally, for the third party food safety certification to be of use Halal certifiers should:

1. Review the results;

2. Understand the risks addressed by the standards;

3. Make risk-reduction decisions based on the results. ${ }^{60}$

Such details are not given in Halal standards. Therefore, it remains unclear how the prescribed food safety measures are exactly incorporated into Halal control processes. Thus, it could be inferred that the current Halal food control practices incline toward the passive Halal and Tayyib food safety approach.

Including food safety assessment into the Halal certification process activities would render the Halal certificate to reflect Tayyib control practices as well. In this case, Halal certifiers would be more concentrated on what is happening in the sector by taking into consideration and addressing various food safety issues. The HCPs (Figure 2. Point 2.5) could offer a valuable starting point and a guide to focus Halal control practices regarding food safety, without losing sight of primary aspects, namely the HCCPs. This would lead to upholding the integrity of both the Halal and Tayyib concept and allow to place a "Halal and Tayyib" label on product packaging. By addressing HCPs food-handling companies' would improve their food safety performance, since hygienic practices, specifically hand washing, are crucial in preventing foodborne disease. This would ultimately lead to safer final products justifying non-Muslims' preference of Halal products. ${ }^{76,77}$ Consider gaps in governmental food safety regulation ${ }^{78-80}$ and enforcement (2.6) would even more further Tayyib assurance practices. The active Halal and Tayyib food safety approach is definitely something the Halal food sector should strive toward. The implementation and control of HCPs, being an inherent part of the Halal and Tayyib concept, would lead to not only a better food safety compliance, but also to properly following the Halal and Tayyib requirements.

\section{Conclusion}

The research on food safety and hygiene requirements in Halal food production lead to the formation of the concept of Halal prerequisites. These are an intrinsic part of the Halal concept, which should be implemented throughout the sector to achieve both Halal and Tayyib assurance. This paper also suggests the HCPs as an addition to the HACCP Halal system. In which case, the Halal prerequisites would be incorporated as HCPs to the system along with the sector specific $\mathrm{HCP}$, like in the meat and poultry production. Incorporating either the specified Halal prerequisites or the HCPs to Halal standards and Halal certification procedures, would allow transforming the Tayyib concept from theory to reality. Since currently, the Halal certifiers have a passive approach towards Tayyib assurance. They rely on just the existence of food safety certificates and regulations and in this case, the certificate itself does not reflect Tayyib control practices during Halal audits.

Although, food safety and hygiene (Tayyib) are an intrinsic part of the Halal concept, Halal standards lack details on the subject and quote general hygiene principles and food safety standards. Therefore, as a minimum, checking the food certification reports and governmental inspection reports should be included in the Halal standards and certification process. However, including food safety assessment into the Halal standards and certification process would render the Halal certificate to reflect Tayyib control practices and the Halal food sector to have an active approach toward Tayyib assurance. In order to do that the Halal standards makers and certifiers have to consider Halal prerequisites. These offer a valuable starting point and a guide to focus Halal control practices regarding food safety. This would also enable food-handling companies to improve their food safety performance, since hygienic practices, specifically hand washing, are crucial in preventing foodborne disease. This would ultimately lead to safer final products justifying non-Muslims' preference of Halal products.

\section{Acknowledgement}

None.

\section{Conflict of interest}

The authors' don't have any conflict of interest towards the publication of this paper.

\section{References}

1. WHO estimates of the global burden of foodborne disease. 2015.

2. Nyarugwe SP, Linnemann A, Hofstede GJ, et al. Determinants for conducting food safety culture research. Trends in Food Science \& Technology. 2016;(56):77-87. 
3. Barlow SM, Boobis AR, Bridges J, et al. The role of hazard- and risk-based approaches in ensuring food safety. Trends in Food Science \& Technology. 2015;46(2):176-188.

4. Motarjemi Y, Mortimore S. Industry's need and expectations to meet food safety, $5^{\text {th }}$ international meeting: NoordWijk food safety and HACCP forum 9-10 December 2001. Food Control. 2005;(16):523529.

5. Salaam Gateway. Resolving the current inefficiencies in the global regulation of Halal Food. sl Salaam Gateway. 2016.

6. Ali MH, Tan KH, Ismail MD. A Supply Chain Integrity Framework for Halal Food. British Food Journal. 2017;119(1):20-38.

7. Soon JM, Chandia M, Regenstein JM. Halal Integrity in the Food Supply Chain. British Food Journal. 2017;119(1):39-51.

8. Othman B, Shaarani SM, Bahron A. Evaluation of Knowledge, Halal Quality Assurane Practices and Commitment Among Food Industries in Malaysia. British Food Journal. 2016;118(8):2033-2052.

9. Demirci MN, Soon JM, Wallace CA. Positioning food safety in Halal assurance. Food Control. 2016;(70):257-270.

10. Lau AN, Jamaludin MH, Soon JM. Quality assurance and hala control points for the food industry. Nutrition and Food Science. 2016;46(4):557-570.

11. Iqbal NFK. From Permissible to Wholesome: Situating Halal Organic Farms within The Sustainability Discourse. Islamic Sciences. 2015;13(1):49-56.

12. Raheem FS. Jurisprudence of Halal and Haraam. 2016.

13. Raheem SF. Consumption of Arthropods. 2017.

14. FAO \& WHO. Food Hygiene: Basic Texts. $4^{\text {th }}$ ed, Rome: Electronic Publishing Policy and Support Branch, Communication Division; 2009.

15. WHO guidelines on hand hygiene in health care-first global patient safety challenge: clean care is safer care. Geneva: WHO Press; 2009.

16. Latif IA, Mohamed Z, Sharifuddin J. A Comparative Analysis of Global Halal Certification Requirements. Journal of Food Products Marketing. 2014;20(Suppl 1):85-101.

17. Annabi CA, Ibidapo-Obe OO. Halal certification organizations in the United Kingdom: An exploration of halal cosmetic certification. Journal of Islamic Marketing. 2017;8(1):107-126.

18. Khan MI, Haleem A. Understanding "Halal" and "Halal certification $\&$ accreditation system"-a brief review. Saudu Journal of Business and Management Studies. 2016;1(1):32-42.

19. Al-Mazeedi HM, Regenstein JM, Riaz MN. The Issue of Undeclared Ingredients in Halal and Kosher Food Production: A Focus on Processing Aids. Comprehensive Reviews in Food Science and Food Safety. 2013;12(2):228-233.

20. Muslim ND. Sahih Muslim. Beroot: Daar ul Ihya Il Turath.

21. Awan JA, Sohaib M. Halal and humane slaughter; Comparison between Islamic teachings and modern methods. Pakistan Journal of Food Science. 2016;26(4):234-240.

22. Shafi M. Ma'rif ul Qura'n. Karachi: Ma’rif ul Qura’n. 2014

23. Bin Hammad I. Ba. In: Al Sihah. 4th ed. Beroot: Daar ul Ilm. 1987. $173 \mathrm{p}$.

24. Razi F. 1420 Hijri. Tafseer e Kabeer. $3^{\text {rd }}$ ed. Beroot: Daar ibn Katheer.

25. Aloosi M. 1415 Hijri. Rooh ul Ma’ni. Beroot: Daar ul Kutub.

26. Schmidt RH, Rodrick G. Food safety handbook. New Jersey: John Wiley \& Sons; 2003.
27. Hassan $\mathrm{MH}$, Arif $\mathrm{S}$, Sidek $\mathrm{S}$. Compliance With the Internal Halal Assurance System Among Food Service Operators in Melaka. International Symposium on Research in Innovation and Sustainability. 2014;26(4):1553-1556.

28. Thomas AM, White GRT, Plant E, et al. Challenges and Practices in Halal Meat Preparation: a Case Study Investigation of a UK slaughterhouse. Total Quality Management. 2015;28(2):12-31.

29. Ahmad AN, Rahman RA, Othman M, et al. Critical success factors affecting the implementation of halal food management systems: Perspective of halal executives, consultants and auditors. Food Control. 2017;(74): 70-78.

30. Ab Talib MS, Abdul Hamid AB, Ai Chin T. Motivations and limitations in implementing Halal Food certification: a Pareto analysis. British Food Journal. 2015;117(11):2664-2705.

31. Che Din R, Daud S. Critical Success Factors of MS1500:2009 Implementation. Procedia-Social and Behavioranl Sciences. 2014;(121):96-103

32. Duad S, Che Din R, Bakar S, et al. Implementation of MS1500:2009: A Gap Analysis. IBIMA Publishing. 2011. 11 p.

33. Hassan $\mathrm{MH}$, Arif S, Sidek S. Knowledge and Practice for Implementing Internal Halal Assurance System Among Hala Executives. Asian Social Sciences. 2015;11(17):57-66.

34. Al Baheeqi A. Shiab il Emaan. Riadh: Maktabat ur Rushd. 2003.

35. Nasa'i A. Sunan an- Nasa'I. $2^{\text {nd }}$ ed. Halb: Maktabat Ul Matboaat. 1986.

36. Lelieveld HLM, Holah JT, Napper D. Hygiene in food processingPrinciples and practices. $2^{\text {nd }}$ ed. Cambridge: Woodhead Publishing Limited; 2014. 640 p.

37. Ibn Majah M. Sunan Ibn Majah. Halb: Daar ul Ihya il Kutub Al Arabiah.

38. Al Bukhari M, 1422 Hijri. Sahih Bukhari. Beroot: Daar ul Tawqal Naijah.

39. Abu Dawood S, n.d. Sunan abi Dawood. Beroot: Maktabat ul Asria.

40. Tirmidhi AIM. Jamiah al Tirmidhi. Beroot: Daar ul Garb Al Islami. 1998.

41. Aboul-Enein BH. The miswak (Salvadora persica L.) chewing stick: Cultural implications in oral health promotion. The Saudi Journal for Dental Research. 2014;5(1):9-13.

42. Aruoma OI. The Impact of food regulation on the food supply chain. Toxicology. 2006;221(1):119-127.

43. Snyder OP. Hand Washing for Retail Food Operations-A Review. Dairy. Food and Encironmental Sanitation. 1998;18(3):149-162.

44. Hao WL, Lee YK. Microflora of the Gastrointestinal Tract-a review. Methods Mol Biol. 2004;268:491-502.

45. Guzewich J, Ross MP. Evaluation of Risks Related to Microbiological Contamination of Ready-to-Eat Food by Food Preparation Workers and the Effectiveness of Interventions to Minimize those Risks. Washington, DC; 1999.

46. Riazus Saliheen N, Riaz us Saliheen. Beroot: Daar ibn Katheer. 2007.

47. Tanner B. Independent Assessment by Third-party Certification Bodies. Food Control. 2000;11(5):415-417.

48. Deaton BJ. A Theoretical Framework for Examining the Role of Third-party Certifiers. Food Control. 2004;15(8):615-619.

49. OIC/SMIIC, General Guidelines on Halal Food, Istanbul: SMIIC 2011. 
50. Salaam Gateway. Resolving the current inefficiencies in the global regulation of Halal Food. sl: SalaamGateway. 2016.

51. PSQCA. PS: 3733-2016(R) Pakistan standard specification for halaal food management systems requirements for any organisation in the food chain. Karachi. 2016.

52. Psomas EL, Kafetzopoulos DP. HACCP effectiveness between ISO 22000 certified and non-certified dairy companies. Food Control. 2015;(53):134-139.

53. ISO. The ISO Survey of Management System Standard Certifications 2015.

54. Standards Malaysia. MS1500(2009)(English): Halal FoodProduction, Preparation, Handling and Storage-General Guidlines (Second Revision), Selangor Darul Ehsan: Department of Standards of Malaysia. 2009.

55. IHI Alliance Logistics, Kuala Lumpur: International Halal Integrity Alliance LTD. 2010

56. Standards Malaysia. MS 2400-1:2010 Halalan-Toyyiban assurance pipeline-Part 1: Management system requirements for transportation of goods and/or cargo chain servises, Jalan Usahawan: Department of Standards Malaysia. 2010.

57. Standards Malaysia. MS 2400-2:2010 Halalan-Toyyiban assurance pipeline-Part 2: Management system requirements for warehousing and related activities, Jalan Usahawan: Department of Standards Malaysia. 2010.

58. Standards Malaysia. MS 2400-3:2010 The Halalan-Toyyiban Assurance Pipeline Part 3: Management system requirements for retailing, Jalan Usahawan: Department of Standards Malaysia. 2010

59. Powell DA. Audits and inspections are never enough: a critique to enchance food safety. Food Control. 2013;30(2):686-691.

60. Mortimore S, Wallace C. HACCP a practical approach. $3^{\text {rd }}$ ed. New York: Springer; 2013.

61. Trienekens J, Zuurbier P. Quality and safety standards in the food industry, developments and challenges. International Journal of Production Economics. 2008;113(1):107-122.

62. Hobbs JE, Fearne A, Spriggs J. Incentive structures for food safety and quality assurance: an international comparison. Food Control. 2002;13(2):77-81.

63. Ababouch L. The role of government agencies in assessing HACCP. Food Control. 2000;11(2):137-142.

64. Mortimore S, Wallace C. HACCP a practical approach. $3^{\text {rd }}$ ed. New York: Springer; 2013.

65. Albersmeier F, Schulze H, Jahn G, et al. The Reliability of Third- party Certification in the Food Chain: From checklists to riskorientated auditing. Food Control. 2009;20(10):927-935.

66. Dzwolak W. Assessment of food allergen management in small food facilities. Food Control. 2017;(73):323-331.

67. Taylor E. HACCP in small companies: benefit or burden? Food Control. 2001;12(4):217-222.

68. FAO and WHO, FAO/WHO guidance to governments on the application of HACCP in small and/or less-developed food businesses, Geneva; 2006.

69. Walker E, Pritchard C, Forsythe S. Hazard analysis critical control point and prerequisite programme implementation in small and medium size food businesses. Food Control. 2003;14(3):169-174.

70. Taylor E. HACCP in small companies: benefit or burden?. Food Control. 2001;12(4):217-222.

71. Riaz MN. Halal: An Emerging Food Quality Standard - Similarities of Halal and HACCP. 2009.

72. Jin S, Zhou J, Ye J. Adoption of HACCP system in the Chinese food industry: A comparative analysis. Food Control. 2008;19(8):823828.

73. Wallace C, Williams T. Pre-requisites: a help or a hinderance to HACCP? Food Control. 2001;12(4):235-240.

74. Kohilavani. Embedding Islamic dietary requirements into HACCP approach. Food Control. 2013;34(2):607-612

75. Mortimore SE, Wallace CA. HACCP: A Food Industry Briefing. $2^{\text {nd }}$ edn. Chichester: Wiley Blackwell 2015.

76. ESMA. Halal products-Part one: General Requirements for Hala Food, ESMA Dubai; 2015.

77. Neio Demirci M, Soon JM, Wallace CA. Positioning food safety in Halal assurance. Food Control. 2016;(70):257-270.

78. Van der Meulen B. Private food law-Governing food chains through contract law, self-regulation, private standards, audits and certiication schemes. Wageningen Academic Publishers; 2011.

79. Tanner B. Independent Assessment by Third-party Certification Bodies. Food Control. 2000;11(5):415-417.

80. SGS. Comparing Global Food Safety Initiative (GFSI) recognised standards. 2011. 